\title{
Antifungal Potential of Trichoderma asperellum against Root Rot of Sesamum indicum $L$.
}

\author{
B. Meena* \\ Regional Research Station, Tamil Nadu Agricultural University, \\ Vridhachalam-606 001, Tamil Nadu, India \\ *Corresponding author
}

\section{A B S T R A C T}

Keywords

Sesame,

Trichoderma asperellum, Farm Yard Manure, Macrophomina phaseolina

Article Info

Accepted:

14 May 2020

Available Online:

10 June 2020
Management of root rot disease of sesame caused by Macrophomina phaseolina (Tassi) Goid is challenging and requires an integral approach. The present study was carried out to evaluate the effect of bioagent, Trichoderma asperellum and organic amendment in suppressing the root rot disease of sesame. From the results, it was found that soil application of T. asperellum $(2.5 \mathrm{~kg} / \mathrm{ha})$ mixed with Farm Yard Manure at the rate of 150 $\mathrm{kg}$ and applied as basal was effective for the management of root rot disease of sesame. Moreover, this treatment also scored maxiumum seed yield under field conditions. Soil application of T. asperellum $(2.5 \mathrm{~kg} / \mathrm{ha})$ mixed with FYM at the rate of $100 \mathrm{~kg}$ and applied as basal was found to be the next best in managing root rot disease. This trend was observed during the two successive growing seasons of kharif 2019 and rabi/summer 2019.

\section{Introduction}

Sesame (Sesamum indicum L.) is an important and ancient oil-yielding crop. Among the oilseed field crops, sesame is one of the most important crop in the world for edible oil production. Sesame seed is a rich source of protein $(20 \%)$, edible oil $(50 \%)$, oleic acid (47\%) and linolenic acid (39\%) (Kumaraswamy et al., 2015). Although sesame is widely used for different purposes, it has low productivity due to non-availability of high-yielding varieties, resistant variety to biotic and abiotic stresses, low harvest index, seed shattering and indeterminate growth habit (Meena and Ezhilarasi, 2019).

Among the diseases, root rot of sesame caused by Macrophomina phaseolina (Tassi.) Goid is one of the most devastating diseases occurring in tropical and subtropical countries. It is the destructive disease in all sesame growing areas and causes about 5$100 \%$ yield loss as estimated by Vyas et al., 
(1984), while Maiti et al., (1988) reported an estimated yield loss of $57 \%$ at about $40 \%$ of disease incidence.

The root rot disease is characterized by sudden wilting of growing plants, yellowed leaves, root rot and minimal yield. The disease is both seed and soil borne and usually infects the crop under dry and warm conditions. Sesame is mostly grown as a rainfed crop and under this situation, the crop is exposed to sufficient soil moisture during its initial growth stages (up to 30-35 days), while subsequently the crop is maintained as a dry crop. High temperature and water stress during growing season favours the pathogen's incidence (Chattopadhyay and Kalpana Sastry, 1998).

Due to the harmful effects and development of resistance in crop pathogens by use of chemicals, the biological-based alternatives were used to manage the diseases of various crops. Bioagents served as an ecologically safe and acceptable substitute for the fungicidal management of soil-borne diseases in recent years (Abada and Ahmad, 2014).

Root colonized with biocontrol agents not only suppresses the disease but also helps in increasing the growth of plant by increasing the uptake of nutrients by roots or by releasing the plant hormones (Harman et al., 2004). The abundance of Trichoderma in various soils is coupled with their ability to degrade organic substrates, their metabolic versatility, their resistance to microbial inhibitors, the depedence on prevailing conidions, strains involved, and active competitive saprophytic ability.

For the effective use of Trichoderma spp. in biological control of soil borne plant pathogens, it is necessary that the antagonist is able to survive, grow and proliferate in the soil and rhizosphere.
Ecologically, this has been difficult because of the general inability of introduced alien microorganisms to survive in soils for a variety of reasons. Despite this problem, research in the area of biological control of soil borne plant pathogens with introduced antagonists has increased significantly.

Trichoderma harasperellum have multiple mechanisms of action, including coparasitism via production of chitinases, $\beta-1-3$ glucanases and $\quad 3-1-4 \quad$ glucanases, antibiotics, competition, solubilization of inorganic plant nutrients, induced resistance and inactivation of the pathogen's enzymes involved in the infection process (Harman, 2006).

In In addition to these modes of action, Trichoderma also acts as inducer for resistance in treated plants against certain pathogens (Harman, 2006) and can grow within wide range of temperature and other environmental conditions (Zaman et al., 2015).

Another approach to suppress the soil-borne diseases is to use organic amendments (Bonanomi et al., 2018). Pandey et al., (2011) reported that when fungal antagonists were used in combination with organic amendments, their antagonistic efficacy was enhanced.

These bio-intensive methods can be used to keep the economic threshold level below without harming the agroecosystem of soil and also promoting the growth and productivity of mungbean.

The present study was carried out to standardize the dosage of Farm Yard Manure for mixing with Trichoderma asperellum talc formulation and method of application of bioformulation for the management of root rot of sesame incited by Macrophomina phaseolina. 
Materials and Methods

\section{Isolation of pathogen}

The pathogen $M$. phaseolina was isolated from the infected roots of sesame and maintained on potato dextrose agar (PDA) slants (Rangaswami, 1972).

Standardisation of FYM dose with bioinoculant, Trichoderma asperellum as soil application for the management of root rot

Field experiments were conducted in the New Farm, Regional Research Station, Vridhachalam during kharif 2019 and rabi/summer 2019 to standardize different dosages of Farm Yard Manure for mixing with $T$. asperellum for soil application so as to manage the root rot disease of sesame under sick plot conditions.

The experiments were conducted in a plot size of $2.4 \times 3.0 \mathrm{~m}$ with seven treatments and three replications in RBD using the variety VRI-1 for the management of root rot of sesame. Soil application of T. asperellum was made at the rate of $2.5 \mathrm{~kg} / \mathrm{ha}$. Farm Yard Manure was mixed with $T$. asperellum at different rates $v i z ., 50 \mathrm{~kg}, 100 \mathrm{~kg}$ and $150 \mathrm{~kg}$.

One set of T. asperellum mixed with Farm Yard Manure was applied as basal and another set at 30 days after sowing. Seeds not treated with bioagent served as the control. The germination percentage was observed at 10 days after sowing.

The root rot disease incidence was recorded on 75 days after sowing by counting the number of infected plants and total number of plants. Seed yield was also recorded for each treatment and the data were statistically analyzed. Per cent disease incidence was calculated using the formula

$$
\text { Disease Incidence }(\%)=\frac{\text { Number of infected plants }}{- \text { Total number of plants }} \times 100
$$

\section{Results and Discussion}

A promising strategy for the replacement of chemicals has been the implementation of biocontrol technology, used individually or as an integrated pest management component. Biocontrol preparations of both fungi and bacteria have been applied to seeds, seedlings, and planting media in several ways to reduce plant diseases in the field with various degrees of success.

One of the major biocontrol agents which reduce soil borne diseases of various crops include isolates of the fungus Trichoderma spp. (Balode, 2010). The abundance of Trichoderma in various soils is coupled with their ability to degrade organic substrates, their metabolic versatility, their resistance to microbial inhibitors, the depedence on prevailing conidions, strains involved, and active competitive saprophytic ability (Ali et al., 2012).

The results of the Trial I conducted during kharif 2019 revealed that all the treatments were found to be superior over control. The germination percentage varied from $78.6 \%$ to $92.4 \%$ in the treatments. Among the different treatments tested, soil application of T. asperellum $(2.5 \mathrm{~kg} / \mathrm{ha})$ mixed with FYM at the rate of $150 \mathrm{~kg}$ and applied as basal was found to be effective for the management of root rot disease of sesame which recorded 28.4 per cent disease incidence (Table 1).

The results were in agreement with Choudhary and Ashraf (2019) who reported that $T$. harzianum combined with neem cake effectively enhanced the per cent germination $(93.33 \%)$ and decreased the per cent dry root rot disease mortality $(11.67 \%)$ in mungbean. 
Augmentation of soil with different biological treatments i.e., Trichoderma harzianum cultured on sugar cane bagasse, $T$. harzianum (spore suspension $5 \times 10^{6} \mathrm{cfu} / \mathrm{ml}$ ) and plant guard (biocide), successfully controlled Fusarium solani, F. oxysporium and Macrophomina phaseolina, the main pathogens of root rot disease on grapevine (El-Mohamedy et al., 2010).

Soil application of $T$. asperellum $(2.5 \mathrm{~kg} / \mathrm{ha})$ mixed with FYM at the rate of $100 \mathrm{~kg}$ and applied as basal was found to be the next best in managing root rot disease with 32.6 per cent disease incidence. Soil application of $T$. asperellum $(2.5 \mathrm{~kg} / \mathrm{ha})$ mixed with FYM @ $100 \mathrm{~kg}$ and applied at 30 DAS recorded the disease incidence of $35.3 \%$. The maximum root rot disease incidence of $52.6 \%$ was observed in the control (Table 1). Fiki and Farouk (2017) reported maximum inhibition of soil borne pathogens viz., Rhizoctonia solani, Fusarium solani, F. oxysporum and $M$. phaseolina by $T$. harzianum. Antibiotics like trichodermin, trichodermol A, harzianolide, viridian and gliotoxin produced by Trichoderma spp. helped in suppressing the disease through reduction of germination and production of spore (Khan and Anwer, 2011).

In general, soil application of $T$. asperellum mixed with FYM and applied as basal treatment was found to be superior over application at 30 days after sowing. Ali et al., (2012) highlighted that inoculating Trichoderma into the soil as mycelial preparations grown on rice husks, resulted in better survival and proliferation and effectively controlled damping -off of tomato. Rajan et al., (2002) showed the biocontrol and disease suppression activities of T. harzianum (MTTC 5179) in black pepper against foot rot disease at field conditions; which was found to be efficiently proliferating in the soil and remained in the soil for long time, apart. The seed yield was found to be maximum (593 $\mathrm{kg} / \mathrm{ha}$ ) in soil application of $T$. asperellum $(2.5 \mathrm{~kg} / \mathrm{ha})$ enriched with FYM at the rate of $150 \mathrm{~kg}$ and applied as basal. The minimum seed yield of $456 \mathrm{~kg} / \mathrm{ha}$ was observed in the control (Table 1).

In the Trial II conducted during rabi/summer 2019 on the effect of $T$. asperellum for the management of root rot disease of sesame revealed that soil application of $T$. asperellum $(2.5 \mathrm{~kg} / \mathrm{ha})$ mixed with FYM at the rate of $150 \mathrm{~kg}$ and applied as basal recorded the maximum germination percentage of $91.7 \%$ as against the minimum germination percentage of $80.6 \%$ in the control (Table 2). The highest plant survival percentage and improved yield components were observed by T. asperellum in strawberry (Pastrana et al., 2016). Soil application of $T$. asperellum (2.5 $\mathrm{kg} / \mathrm{ha}$ ) mixed with FYM at the rate of $150 \mathrm{~kg}$ and applied as basal recorded the minimum root rot disease incidence of $16.4 \%$. Soil application of $T$. asperellum $(2.5 \mathrm{~kg} / \mathrm{ha})$ mixed with FYM @ $100 \mathrm{~kg}$ as basal application ranked next in managing root rot disease with $17.8 \%$ disease incidence. The maximum root rot disease incidence of $31.4 \%$ was observed in the control (Table 2). Maximum growth inhibition of soil borne pathogens viz., Macrophomina phaseolina, Rhizoctonia and Fusarium was observed by $T$. harzianum (Ahmed and El-Fiki, 2017).

In addition to disease reduction, the maximum seed yield of $578 \mathrm{~kg} / \mathrm{ha}$ was observed in the treatment comprising of soil application of T. asperellum $(2.5 \mathrm{~kg} / \mathrm{ha})$ enriched with FYM at the rate of $150 \mathrm{~kg}$ and applied as basal as against the minimum seed yield of $442 \mathrm{~kg} / \mathrm{ha}$ in the control (Table 2). Hohmann et al., (2012) reported that despite isolate specific recovery of the introduced isolate, that total propagule counts do not always correlate with the amount of viable mycelium present in the root system. 
Table.1 Management of root rot by Trichoderma asperellum and FYM (Trial I-kharif 2019)

\begin{tabular}{|c|c|c|c|c|}
\hline S.No. & Treatments & $\begin{array}{c}\text { Germination } \\
(\%)\end{array}$ & $\begin{array}{c}\text { Root rot } \\
\text { incidence }(\%)\end{array}$ & $\begin{array}{l}\text { Yield } \\
\text { (kg/ha) }\end{array}$ \\
\hline $\mathbf{T}_{1}$ & $\begin{array}{l}\text { Soil application of Trichoderma asperellum ( } 2.5 \\
\mathrm{~kg} / \mathrm{ha} \text { ) mixed with FYM @ } 50 \mathrm{~kg} \text { as basal } \\
\text { application }\end{array}$ & $\begin{array}{c}86.3 \\
(68.2)\end{array}$ & $\begin{array}{c}38.4 \\
(38.2)\end{array}$ & 546 \\
\hline $\mathbf{T}_{2}$ & $\begin{array}{l}\text { Soil application of } T \text {. asperellum }(2.5 \mathrm{~kg} / \mathrm{ha}) \text { mixed } \\
\text { with FYM @ } 100 \mathrm{~kg} \text { as basal application }\end{array}$ & $\begin{array}{c}89.2 \\
(70.8)\end{array}$ & $\begin{array}{c}32.6 \\
(34.7)\end{array}$ & 576 \\
\hline $\mathbf{T}_{3}$ & $\begin{array}{l}\text { Soil application of } T \text {. asperellum }(2.5 \mathrm{~kg} / \mathrm{ha}) \text { mixed } \\
\text { with FYM @ } 150 \mathrm{~kg} \text { as basal application }\end{array}$ & $\begin{array}{c}92.4 \\
(74.0)\end{array}$ & $\begin{array}{c}28.4 \\
(32.1)\end{array}$ & 593 \\
\hline $\mathbf{T}_{4}$ & $\begin{array}{l}\text { Soil application of } T \text {. asperellum }(2.5 \mathrm{~kg} / \mathrm{ha}) \text { mixed } \\
\text { with FYM @ } 50 \mathrm{~kg} \text { at } 30 \text { DAS }\end{array}$ & $\begin{array}{c}82.9 \\
(65.5)\end{array}$ & $\begin{array}{c}41.7 \\
(40.2)\end{array}$ & 498 \\
\hline $\mathbf{T}_{5}$ & $\begin{array}{l}\text { Soil application of } T \text {. asperellum }(2.5 \mathrm{~kg} / \mathrm{ha}) \text { mixed } \\
\text { with FYM @ } 100 \mathrm{~kg} \text { at } 30 \text { DAS }\end{array}$ & $\begin{array}{l}85.7 \\
(67.7)\end{array}$ & $\begin{array}{c}35.3 \\
(36.4)\end{array}$ & 565 \\
\hline $\mathbf{T}_{6}$ & $\begin{array}{l}\text { Soil application of T. asperellum }(2.5 \mathrm{~kg} / \mathrm{ha}) \text { mixed } \\
\text { with FYM @ } 150 \mathrm{~kg} \text { at } 30 \text { DAS }\end{array}$ & $\begin{array}{l}91.5 \\
(73.0)\end{array}$ & $\begin{array}{c}37.8 \\
(37.9)\end{array}$ & 552 \\
\hline \multirow[t]{5}{*}{$\mathbf{T}_{7}$} & Control & $\begin{array}{l}78.6 \\
(62.4)\end{array}$ & $\begin{array}{c}52.6 \\
(46.4)\end{array}$ & 456 \\
\hline & C.D. & 2.32 & 2.02 & 13.13 \\
\hline & $\mathrm{SE}(\mathrm{m})$ & 0.74 & 0.65 & 4.21 \\
\hline & $\mathrm{SE}(\mathrm{d})$ & 1.05 & 0.92 & 5.96 \\
\hline & C.V. & 1.87 & 2.96 & 1.35 \\
\hline
\end{tabular}

Mean of three replications

Table.2 Management of root rot by Trichoderma asperellum and FYM

(Trial II-rabi/summer 2019)

\begin{tabular}{|c|c|c|c|c|}
\hline S.No. & Treatments & $\begin{array}{c}\text { Germination } \\
(\%)\end{array}$ & $\begin{array}{c}\text { Root rot } \\
\text { incidence }(\%)\end{array}$ & $\begin{array}{c}\text { Yield } \\
(\mathbf{k g} / \mathrm{ha})\end{array}$ \\
\hline $\mathbf{T}_{1}$ & $\begin{array}{l}\text { Soil application of Trichoderma asperellum ( } 2.5 \\
\mathrm{~kg} / \mathrm{ha} \text { ) mixed with FYM @ } 50 \mathrm{~kg} \text { as basal application }\end{array}$ & $\begin{array}{c}84.6 \\
(66.8)\end{array}$ & $\begin{array}{c}25.6 \\
(30.3)\end{array}$ & 490 \\
\hline $\mathbf{T}_{2}$ & $\begin{array}{l}\text { Soil application of } T \text {. asperellum }(2.5 \mathrm{~kg} / \mathrm{ha}) \text { mixed } \\
\text { with FYM @ } 100 \mathrm{~kg} \text { as basal application }\end{array}$ & $\begin{array}{c}89.4 \\
(71.0)\end{array}$ & $\begin{array}{c}17.8 \\
(24.9)\end{array}$ & 554 \\
\hline $\mathbf{T}_{3}$ & $\begin{array}{l}\text { Soil application of } T \text {. asperellum }(2.5 \mathrm{~kg} / \mathrm{ha}) \text { mixed } \\
\text { with FYM @ } 150 \mathrm{~kg} \text { as basal application }\end{array}$ & $\begin{array}{c}91.7 \\
(73.2)\end{array}$ & $\begin{array}{c}16.4 \\
(23.8)\end{array}$ & 578 \\
\hline $\mathbf{T}_{4}$ & $\begin{array}{l}\text { Soil application of } T \text {. asperellum }(2.5 \mathrm{~kg} / \mathrm{ha}) \text { mixed } \\
\text { with FYM @ } 50 \mathrm{~kg} \text { at } 30 \text { DAS }\end{array}$ & $\begin{array}{c}82.3 \\
(65.1)\end{array}$ & $\begin{array}{c}27.4 \\
(31.5)\end{array}$ & 482 \\
\hline $\mathbf{T}_{5}$ & $\begin{array}{l}\text { Soil application of } T \text {. asperellum }(2.5 \mathrm{~kg} / \mathrm{ha}) \text { mixed } \\
\text { with FYM @ } 100 \mathrm{~kg} \text { at } 30 \text { DAS }\end{array}$ & $\begin{array}{c}88.2 \\
(69.9)\end{array}$ & $\begin{array}{c}19.7 \\
(26.3)\end{array}$ & 513 \\
\hline $\mathbf{T}_{6}$ & $\begin{array}{l}\text { Soil application of } T \text {. asperellum }(2.5 \mathrm{~kg} / \mathrm{ha}) \text { mixed } \\
\text { with FYM @ } 150 \mathrm{~kg} \text { at } 30 \text { DAS }\end{array}$ & $\begin{array}{c}87.1 \\
(68.9)\end{array}$ & $\begin{array}{l}21.6 \\
(27.6)\end{array}$ & 506 \\
\hline \multirow[t]{5}{*}{$\mathbf{T}_{7}$} & Control & $\begin{array}{c}80.6 \\
(63.9)\end{array}$ & $\begin{array}{c}31.4 \\
(34.0)\end{array}$ & 442 \\
\hline & C.D. & 2.14 & 0.89 & 9.836 \\
\hline & $\mathrm{SE}(\mathrm{m})$ & 0.68 & 0.28 & 3.157 \\
\hline & $\mathrm{SE}(\mathrm{d})$ & 0.97 & 0.40 & 4.465 \\
\hline & C.V. & 1.74 & 1.75 & 1.069 \\
\hline
\end{tabular}

Mean of three replications 
Table.3 Management of root rot by Trichoderma asperellum and FYM (Pooled mean)

\begin{tabular}{|c|c|c|c|c|}
\hline S.No. & Treatments & $\begin{array}{c}\text { Germination } \\
(\%)\end{array}$ & $\begin{array}{c}\text { Root rot } \\
\text { incidence }(\%)\end{array}$ & $\begin{array}{l}\text { Yield } \\
\text { (kg/ha) }\end{array}$ \\
\hline $\mathbf{T}_{1}$ & $\begin{array}{l}\text { Soil application of Trichoderma asperellum ( } 2.5 \\
\mathrm{~kg} / \mathrm{ha} \text { ) mixed with FYM @ } 50 \mathrm{~kg} \text { as basal } \\
\text { application }\end{array}$ & $\begin{array}{c}85.4 \\
(66.8)\end{array}$ & $\begin{array}{c}32.0 \\
(34.3)\end{array}$ & 518 \\
\hline $\mathbf{T}_{2}$ & $\begin{array}{l}\text { Soil application of } T . \text { asperellum }(2.5 \mathrm{~kg} / \mathrm{ha}) \\
\text { mixed with FYM @ } 100 \mathrm{~kg} \text { as basal application }\end{array}$ & $\begin{array}{c}89.3 \\
(71.0)\end{array}$ & $\begin{array}{c}25.2 \\
(29.8)\end{array}$ & 565 \\
\hline $\mathbf{T}_{3}$ & $\begin{array}{l}\text { Soil application of } T \text {. asperellum }(2.5 \mathrm{~kg} / \mathrm{ha}) \\
\text { mixed with FYM @ } 150 \mathrm{~kg} \text { as basal application }\end{array}$ & $\begin{array}{c}92.1 \\
(73.2)\end{array}$ & $\begin{array}{c}22.4 \\
(28.0)\end{array}$ & 585 \\
\hline $\mathbf{T}_{4}$ & $\begin{array}{l}\text { Soil application of } T \text {. asperellum }(2.5 \mathrm{~kg} / \mathrm{ha}) \\
\text { mixed with FYM @ } 50 \mathrm{~kg} \text { at } 30 \text { DAS }\end{array}$ & $\begin{array}{c}82.6 \\
(65.1)\end{array}$ & $\begin{array}{l}34.55 \\
(35.8)\end{array}$ & 490 \\
\hline $\mathbf{T}_{5}$ & $\begin{array}{l}\text { Soil application of } T . \text { asperellum }(2.5 \mathrm{~kg} / \mathrm{ha}) \\
\text { mixed with FYM @ } 100 \mathrm{~kg} \text { at } 30 \text { DAS }\end{array}$ & $\begin{array}{c}86.9 \\
(69.9)\end{array}$ & $\begin{array}{c}27.5 \\
(31.3)\end{array}$ & 539 \\
\hline $\mathbf{T}_{6}$ & $\begin{array}{l}\text { Soil application of } T \text {. asperellum }(2.5 \mathrm{~kg} / \mathrm{ha}) \\
\text { mixed with FYM @ } 150 \mathrm{~kg} \text { at } 30 \text { DAS }\end{array}$ & $\begin{array}{c}89.3 \\
(68.9)\end{array}$ & $\begin{array}{c}29.7 \\
(32.7)\end{array}$ & 529 \\
\hline \multirow[t]{5}{*}{$\mathbf{T}_{7}$} & Control & $\begin{array}{c}79.6 \\
(63.9)\end{array}$ & $\begin{array}{c}42.0 \\
(40.2)\end{array}$ & 449 \\
\hline & C.D. & 1.26 & 1.35 & 15.73 \\
\hline & $\mathrm{SE}(\mathrm{m})$ & 0.43 & 0.46 & 5.42 \\
\hline & $\mathrm{SE}(\mathrm{d})$ & 0.61 & 0.66 & 7.66 \\
\hline & C.V. & 1.55 & 3.44 & 2.52 \\
\hline
\end{tabular}

Mean of three replications

The results of the pooled mean of the field experiments conducted during kharif 2019 and rabi/summer 2019 revealed that soil application of $T$. asperellum $(2.5 \mathrm{~kg} / \mathrm{ha})$ mixed with FYM at the rate of $150 \mathrm{~kg}$ and applied as basal was found to be effective for the management of root rot disease of sesame with 22.4 per cent disease incidence (Table $3)$.

The use of organic amendments in reducing disease intensity and increasing grain yield has been reported by several workers (Kapoor et al., 2006). This was followed by the soil application of $T$. asperellum $(2.5 \mathrm{~kg} / \mathrm{ha})$ mixed with FYM at the rate of $100 \mathrm{~kg}$ and applied as basal which recorded 25.2 per cent disease incidence. The maximum root rot disease incidence of $42.0 \%$ was observed in the control (Table 3). Pastrana et al., (2016) reported that $T$. asperellum was the most effective in reduction of crown and root rot caused by Fusarium solani (up to $100 \%$ in greenhouse and $81 \%$ under field conditions. Soil application of T. asperellum $(2.5 \mathrm{~kg} / \mathrm{ha})$ mixed with FYM at the rate of $150 \mathrm{~kg}$ and applied as basal recorded the maximum seed yield of $585 \mathrm{~kg} / \mathrm{ha}$. The minimum seed yield of $449 \mathrm{~kg} / \mathrm{ha}$ was observed in the control (Table 3). The use of organic amendments in reducing disease intensity and increasing grain yield has been reported by several workers (Kapoor et al., 2006).

Treatment with T. harzianum (MTCC 5179) individually imparted better growth promotion and disease suppression than that of a consortia of plant growth-promoting rhizobacteria alone or in combination with $T$. harzianum (MTCC 5179) (Sibi, 2013). These studies indicated growth promotion and the organism was recommended as a component of integrated disease management and without a clear understanding of other mechanisms. Plants contribute to the establishment of specific ecological niches of microbes in the 
rhizosphere by playing key role as ecosystem engineers. The microbial community at the rhizosphere reflects its functional specificity at the level of plant-microbe interactions. It suggests that taxonomically-contrasted plant growth promoting strains may coexist in soil and colonize the same rhizosphere. The high ecological adaptability of members of the genus Trichoderma make these species good candidates for the use in biocontrol applications in a variety of habitats (Longa et al., 2009).

The present study concluded that $T$. asperellum combined withFarm Yard Manure can be recommended as an effective approach for the management of root rot disease of sesame. Bioagents and organic amendments led to increase the level of antagonists result in a decrease of the propagule density of pathogen. This is due to the competition with other microbes or fungitoxic compounds released by them. These bio-intensive methods can be used to keep the economic threshold level below without harming the agroecosystem of soil and also promoting the growth and productivity of sesame.

\section{References}

Ali, M.I., Yasser, M.M., Mousa, A.S. and Abdel Khalek, M. 2012. Optimization of factors affecting proliferation and flourishment of Trichoderma harzianum in Egyptian soil. Journal of Basic \& Applied Mycology, 3 : 41-48.

Abada, M. and Ahmad, M. 2014. A comparative study for th effect of green tea extract and some antioxidants on Thompson seedless grapevines. Int $J$ Plant \& Soil Sci., 3 : 1333-1342.

Ahmed, M.F.A. and El-Fiki, I.A.I. 2017. Effect of biological control of root rot diseases of strawberry using Trichoderma spp. Middle East Journal of Applied Sciences, 7 : 482-492.
Balode, A. 2010. Effect of tricodermin, biological product against Botrytis in horticultural crops. Acta horticulture, 877 : 1583-1588.

Bonanomi, G., Lorito, M., Vinale, F. and Woand, S.L. 2018. Organic amendments, beneficial microbes and soil microbiota : towards a unified framework for disease suppression. Ann Rev of Phytopathol., $56: 1-20$.

Chattopadhyay, C. and Kalpana Sastry, R. 1998. Important diseases of sesame and their management options. In: IPM systems in Agriculture, (Oilseeds), RK Upadhyay, KG Mukerjie, RL Rajak (eds.), Oxford and IBH Publ., New Delhi.

Choudhary, A. and Ashraf, S. 2019. Utilizing the combined antifungal potential of Trichoderma spp. and organic amendments against dry root rot of mungbean. Egyptian Journal of Biological Pest Control, 29 : 1-8.

El-Mohamedy, R.S.R., Ziedan, E.H. and Abdalla, A.M. 2010. Biological soil treatment with Trichoderma harzianum to control root rot disease of grapevine (Vitis vinifera L.) in newly reclaimed lands in Nobaria province. Archives of Phytopathology and Plant Protection, 43 :.73-87.

Fiki, I. and Farouk, M. 2017. Effect of biological control of root rot diseases of strawberry using Trichoderma spp. Research Journal of Applied Sciences, 7 : 482-492.

Harman, G.E. 2006. Overview of mechanisms and uses of Trichoderma spp. Phytopathology, 96 : 190-194.

Harman, G.E., Howell, C.R., Viterbo, A., Chet, I. and Lorito, M. 2004. Trichoderma species -opportunistic, avirulent plant symbionts. Nature Reviews Microbiology, 2 : 43-56.

Hohmann, P., Jones, E.E., Hill, R.A. and Stewart, A. 2012. Ecological studies of 
the bio-inoculant Trichoderma hamatum LU592 in the root system of Pinus radiata. FEMS Microbiol Ecol., $80: 709-721$.

Kapoor, A.S., Paul, Y.S. and Singh, A. 2006. Integrated management of white rot and root rot wilt disease complex of pea. Indian Phytopath., 59 : 467-474.

Khan, M.R and Anwer, A. 2011. Fungal bioinoculants for plant disease management. In: Paul, M., Clinton, M., Ahmad, I. (eds) Microbes and Microbial Technology. Springer, USA, pp 447 488.

Kumaraswamy, H.H., Jawaharlal, J., Ranganatha, A.R.G. and Chander Rao, S. 2015. Safe sesame (Sesamum indicum L.) production : Perspectives, practices and challenges. Journal of Oilseeds Research, $32: 1-24$.

Longa, C.M.O., Savazzini, F., Tosi, S., Elad, Y. and Pertot, I. 2009. Evaluating the survival and environmental fate of the biocontrol agent Trichoderma atroviride $\mathrm{SC} 1$ in vineyards in northern Italy. Journal of Applied Microbiology, $106: 1549-1557$.

Maiti, S., Hegde, M.R., Chattopadhyay, S.B. 1988. Handbook of Annual Oilseed Crops. Oxford and IBH Publ. Co. Pvt. Ltd., New Delhi.

Meena, B. and Ezhilarasi, T. 2019. Fungicides in the management of foliar diseases of sesame. Int. J. Curr. Microbiol. App. Sci., 8 : 3086-3090.
Pandey, P., Kumar, R. and Mishra, P. 2011 Integrated approach for the management of Sclerotinia sclerotiorum (Lib.) de Bary, causing stem rot of chickpea. Indian Phytopathol., 64 : 37-40.

Pastrana, A.M., Ureba, M.J.B., Aguado, A., Akdi, K. and Capote, N. 2016. Biological control of strawberry soilborne pathogens Macrophomina phaseolina and Fusarium solani, using Trichoderma asperellum and Bacillus spp. Phytopathologia Mediterranea, 55 : 109-120.

Rajan, P.P., Sarma, Y.R. and Anandaraj, M. 2002. Management of foot rot disease of black pepper with Trichoderma spp. Indian Phytopathol., 55 : 34-38.

Rangaswami, G. 1972. Diseases of crop plants in India. Prentice Hall of India Pvt. Ltd. New Delhi, p.520.

Sibi, M.C. 2013. The potential of PGPR in disease management of Spice crop. Proceedings of the $6^{\text {th }}$ International PGPR Workshop, Calicut, India, pp.2739.

Vyas, S.C., Kotwel, T., Prasad, K.M.V. and Jain, A.C. 1984. Notes on seed-borne fungi of sesamum and their control. Seed Res., 12 : 93-94.

Zaman, M.A.U., Bhuiyan, M.R.. Khan, M.A.I., Bhuiyan, M.K.A. and Latif, M.A. 2015. Integrated options for the management of black root rot of strawberry caused by Rhizoctonia solani Kuhn. Elsevier SAS, 338 : 112-120.

\section{How to cite this article:}

Meena. B. 2020. Antifungal Potential of Trichoderma asperellum against Root Rot of Sesamum indicum L.. Int.J.Curr.Microbiol.App.Sci. 9(06): 288-295.

doi: https://doi.org/10.20546/ijcmas.2020.906.037 